\title{
Acute disseminated encephalomyelitis in classic dengue
}

\author{
Encefalomielite disseminada aguda em dengue clássica
}

\author{
Carlos A.A. Brito ${ }^{1,2}$, Silvana Sobreira ${ }^{3}$, Marli Tenório Cordeiro ${ }^{1,4}$ and Norma Lucena-Silva ${ }^{1,5}$
}

\begin{abstract}
Neurological manifestation is uncommon in dengue infection. The pathogenesis of central nervous system involvement is controversial. We report a rare case of acute disseminated encephalomyelitis in classic dengue, with isolation of serotype 3 in liquor. This condition was associated with significant structural damage detected by magnetic resonance.
\end{abstract}

Key-words: Acute disseminated encephalomyelitis. Dengue. Neurological symptoms.

\section{RESUMO}

Manifestação neurológica é incomum em dengue. A patogênese do acometimento do sistema nervosa central é controversa. Nós relatamos um raro caso de encefalomielite disseminada aguda em dengue clássica, com isolamento do sorotipo 3 em líquor. O quadro estava associado a significativo dano estrutural detectado pela ressonância magnética.

Palavras-chaves: Encefalite disseminada aguda. Dengue. Manifestações neurológicas.

Dengue is an infectious disease caused by a flavivirus, in which neurological signs are uncommon. Nevertheless, central nervous system (CNS) involvement has been reported with different clinical forms (meningitis or encephalitis), as well as peripheral nervous system disease with clinical signs of polyradiculoneuritis ${ }^{3}{ }^{8}$. The frequency of dengue etiology in patients with encephalitis, based on the presence of anti-dengue IgM in the serum, has been shown to range from 5 to $20 \%^{511}$. The pathogenesis of the neurological manifestation is not clearly defined, but some reports have attributed it to the encephalopathy present in severe cases of dengue hemorrhagic fever (DHF) ${ }^{18}$. Acute disseminated encephalomyelitis (ADEM) is a neurological manifestation rarely described in association with dengue. Four ADEM cases have been published, but only two of them showed abnormalities on nuclear magnetic resonance (NMR) imaging, which were associated with systemic vascular alterations, consumption of platelets and hepatic dysfunctions. The dengue virus was not isolated in liquor in any of these cases $^{3712}$.

The present report details the case of a 37-year-old woman was attended at the emergency services of Memorial São José Hospital in Recife. She presented with asthenia, headache, myalgia and arthralgia, and was using dipyrone as a painkiller. Five days after her symptoms started, she had difficulty in pronouncing some words, and this evolved to progressive impairment in spontaneous speech. She presented weakness in the left hand, which was most pronounced in the first and second fingers. This made the use of tweezers difficult, thereby compromising her professional activity (dentist). She had a sensation of heaviness in her left leg, with repercussions on her gait, and this was the principal preoccupation leading to consultation with a neurologist.

The initial neurological examination showed speech disturbances characterized by phonemic paraphasia and dysnomia, with the preservation of understanding. This was associated with grade III movement deficit in the left hand, which was predominantly in the first and second fingers, and grade IV deficit in the left leg. The superficial and deep reflexes were normal, with slight hypostasis for painful tactile stimulus of the left hand. The cranial pairs were also normal.

Blood assays showed platelets and hepatic enzymes at normal levels (Table 1). NMR gave a low signal on T1 and a high signal on $\mathrm{T} 2$, and showed a variety of contrast impregnations (retentions) with ventricular white substance, at the callosal-septal interface, right-side centrum semiovale, corona radiata and thalamus bilaterally.

\footnotetext{
1. Aggeu Magalhães Research Center, Oswaldo Cruz Foundation, Recife, PE. 2. Departamento de Medicina Clínica, Universidade Federal de Pernambuco, Recife, PE. 3. Hospital Memorial São José, Recife, PE 4. Dr. Milton Bezerra Laboratory, Laboratório Central, Recife, PE. 5. Instituto Materno Infantil de Pernambuco Prof. Fernando Figueira, Recife, PE Support: This work was supported by the PDTSP program at FIOCRUZ.

Address to: Dra. Norma Lucena-Silva. Centro de Pesquisa Aggeu Magalhães/FIOCRUZ. Av. Moraes Rego, S/N, campus da UFPE, Cidade Universitária, $50670-420$ Recife, PE, Brazil Tel: $55812122-4764$.

e-mail: nlucena@cpqam.fiocruz.br

Recebido para publicação em 28/9/2006

Aceito em 8/2/2007
} 
Table 1- Laboratory record of a patient with acute disseminated encephalomyelitis due to classic dengue infection by dengue virus serotype DENV-3.

\begin{tabular}{lr}
\hline Blood analysis & Results \\
\hline Hematocrit (\%) & 38.2 \\
\hline WBC count, cells/ $\mu \mathrm{l}$ & 4,100 \\
\hline Total neutrophil count, cells/ $\mu \mathrm{l}$ & 2,200 \\
\hline Total lymphocyte count, cells/ $\mu \mathrm{l}$ & 1,300 \\
\hline Total monocyte count, cells/ $\mu \mathrm{l}$ & 400 \\
\hline Total eosinophil count, cells/ $\mu \mathrm{l}$ & 100 \\
\hline Platelet count, x 10³/ $\mu$ l (lowest value obtained) & 328 \\
\hline VSM, mm (normal range: 0-20mm) & 22 \\
\hline Aspartate aminotransferase, U/ml & 18 \\
\hline Alanine aminotransferase, $\mathrm{U} / \mathrm{ml}$ & 4.2 \\
\hline Albumin, g/dl (normal range: 3.5 to $5.0 \mathrm{~g} / \mathrm{dl})$ & negative
\end{tabular}

anti-HIV, anti-HTLV I and II, anti-HCV,

anti-HVA and anti-HBSAg, anti-HBc, HBSAg,

VDRL, FTA-ABS and Waaler Rose

$\mathrm{WBC}=\mathrm{VSM}=\mathrm{FAN}=\mathrm{LE}$ cells $=$ anti-DNA $=$ anti- $\mathrm{HIV}=$ anti-HTLV $=$ anti- $\mathrm{HVA}=$ anti- $\mathrm{HBSAg}=$ anti-HBc $=\mathrm{HBSAg}=\mathrm{VDRL}=\mathrm{FTA}-\mathrm{ABS}=$

The dengue etiology was confirmed by isolating the virus from the liquor followed by RT-PCR and immunofluorescence for dengue serotyping. Hemagglutination inhibition (HI) assay detected seroconversion for anti-dengue specific antibodies to DEN-3, as shown in Table 2. A positive HI for other serotype indicates previous dengue infection.

Table 2- Laboratory assays for confirming the diagnosis of dengue infection.

\begin{tabular}{ccccccc}
\hline & & & & \multicolumn{3}{c}{ Hemagglutination inhibition assay } \\
\cline { 5 - 6 } Sample & IgM & Isolation & RT-PCR & DENV-1 & DENV-2 & DENV-3 \\
\hline LCR & - & DENV-3 & DENV-3 & - & - & - \\
May 10, 2004 & & & & & & \\
\hline Serum 1 & - & ND & ND & $1: 320$ & $1: 160$ & $1: 40$ \\
May 14, 2004 & & & & & & \\
\hline $\begin{array}{c}\text { Serum 2 } \\
\text { June 28, 2004 }\end{array}$ & - & ND & ND & $1: 320$ & $1: 160$ & $1: 320$ \\
\hline
\end{tabular}

ND: not done

RT-PCR: reverse transcription-polymerase chain reaction

The patient underwent pulse therapy with $1 \mathrm{~g}$ of methylprednisolone for 5 days.

A sample of liquor was sent to our laboratory for examination on the fifth day of symptoms when she was seen by the physician for the first time. It was only on the ninth day of disease, after laboratory confirmation of dengue in the liquor, that a new blood sample was collected, when virus isolation is more difficult. Anti-dengue IgM was also negative in both the serum and liquor. Negative ELISA has also been reported in $25 \%$ out of 614 cases of acute infection confirmed by hemagglutination inhibition ${ }^{4}$.

Neurological manifestations have not been directly attributed to the effect of the virus, but to dengue encephalopathy caused by systemic vascular alterations. Such alterations might be due to the homeostasis, vascularized endothelium or hepatic dysfunction that is present in severe cases of dengue hemorrhagic fever $(\mathrm{DHF})^{18}$.

The molecular pathogenesis of neurological dengue has become a subject for study because of the increasing numbers of reports of neurological symptoms among patients with mild DHF or classic dengue ${ }^{50}$. Additionally, some necropsy studies have been suggesting that local inflammatory activity is due to the presence of the virus in the $\mathrm{CNS}^{269}$.

ADEM is an uncommon neurological manifestation involving peripheral nerves that has also been associated with dengue infection. Two recently reported cases of ADEM suggested this association, but no clinical and laboratory evidence has been produced to support the hypothesis that the virus has a cytopathic effect on the $\mathrm{CNS}^{312}$.

Out of 41 reported cases of dengue with neurological manifestations among Brazilian patients, 22 were classified as encephalitis, 16 as peripheral nervous disease, two as transversal myelitis and one as ADEM. In the ADEM case, no virus was isolated from liquor, nor were there any abnormalities on NMR. There was no information about the clinical form of the dengue, platelet counts or hepatic dysfunction to add to the discussion on the genesis of these neurological manifestations ${ }^{3}$.

There has been another report of ADEM, on a Japanese patient infected in Brazil, in which the NMR images of the spinal cord showed multiple high-intensity spotty lesions from Th-7 to Th-11. This case showed a notable decrease in platelet count $(50,000 / \mu \mathrm{l})$ and also hepatic dysfunction, thus suggesting a mechanism associated with dengue encephalopathy ${ }^{12}$.

We have reported an ADEM case that was associated with dengue virus detected in the liquor and significant structural damage detected by NMR. This was classified as a classic dengue case without evidence of the hepatic dysfunction, circulatory collapse, hypoxia or metabolic imbalance that occur secondarily to encephalopathy. These features emphasize that a cytopathic effect was occurring due to the presence of the virus in the CNS. Future studies will be needed to clarify whether the neurological manifestations are due to neural tropism or the virulence of a variant virus of the dengue virus.

\section{REFERENCES}

1. Cam BV, Fonsmark L, Hue NB, Phuong NT, Pousen A, Heegaard ED. Prospective case-control study of encephalopathy in children with dengue hemorrhagic fever. The American Journal of Tropical Medicine and Hygiene 66:848-851, 2001.

2. Chimelli L, Hahn MD, Netto MB, Ramos RG, Dias M, Gray F. Dengue: neuropathological findings in 5 fatal cases from Brazil. Clinical Neuropathology 9:157-162, 1990

3. Ferreira LMB, Cavalcanti CG, Coelho CA, Mesquita SD. Neurological manifestation of dengue: study of 41 cases. Arquivos de Neuro-psiquiatria 63:488-493, 2005.

4. Harris E, Videa E, Pérez L, Pérez L, Sandoval E, Téllez Y, Pérez MLA, Cuadra R, Rocha J, Idiaquez W, Alonso RE, Delgado MA, Campo LM, Acevedo F, Gonzales A, Amador JJ, Balmaseda A. Clinical, epidemiologic, and virologic features of dengue in the 1998 epidemic in Nicaragua. The American Journal of Tropical Medicine and Hygiene 63:5-11, 2000.

5. Kankirawatana P, Chokephaibulkit K, Puthavathana P, Yoksan S, Apintanapong $S$, Pongthapisit V. Dengue infection presenting with central nervous system manifestation. Journal of Child Neurology 15:544-547, 2000. 
6. Miagostovich MP, Ramos RG, Nicol AF, Nogueira RM, Cuzzi-Maya T, Oliveira AV, Marchevsky RS, Mesquita RP, Schtzamyr HG. Retrospective study on dengue fatal cases. Clinical Neuropathology 16:204-8, 1997.

7. Misra UK, Kalita J, Syan UK, Dhole TN. Neurological manifestation of dengue virus infection. Journal of the Neurological Sciences 244:117-122, 2006.

8. Nimmannitya S, Thisyakorn U, Hemsrichart V. Dengue haemorrhagic fever with unusual manifestations. The Southeast Asian Journal of Tropical Medicine and Public Health 8:398-406,1987.

9. Ramos C Sánchez G, Pando RH, Baquera J, Hernández D, Mota J, Ramos J, Flores A, Llausás E. Dengue virus in the brain of fatal case of hemorrhagic dengue fever. Journal of Neurovirology 4:465-468, 1998.
10. Santos NQ, Azoubel AC, Lopes AA, Costa G, Bacellar A. Guillain-Barré syndrome in the course of dengue. Case report. Arquivos de Neuro-psiquiatria 62:144-146, 2004.

11. Pancharoen $\mathrm{C}$, Thisyakorn U. Neurological manifestations in dengue patients. The Southeast Asian Journal of Tropical Medicine and Public Health 32:341-345, 2001.

12. Yamamoto Y, Takasaki T, Yamada K, Kimura M, Washizaki K, Yoshikawa K, Hitani A, Nakamura T, Iwamoto A. Acute disseminated encephalomyelites following dengue fever. Journal of Infection and Chemotherapy 8:175-177, 2002 